\title{
Increasing Economic Empowerment of the People through Productive Waqf
}

\section{Aripin Marpaung}

Faculty of Sharia and Law, Universitas Islam Negeri Sumatera Utara, Indonesia Email: arifinmarpaung@uinsu.ic.id

\begin{abstract}
:
Post-press freedom in Indonesia (the passing of Law No. 40/1999) gave rise to a variety of new problems, ranging from widespread violations of the Journalistic Code of Ethics (KEJ) to violence against journalists. In fact, the Press Law No. 40/1999 was actually born to provide fresh air for press freedom in the country and to provide the widest possible space for press operations that were previously locked in the shackles of power. The results of the discussion found that violations of the journalistic code of ethics tended to be committed by young journalists who were still raw with the articles of the code of ethics and the Press Law No. 40/1999. Forms of violation are sometimes reluctant to confirm sources, using fictitious anonymous sources, do not keep the identity of victims of immoral crimes secret, use bar language, and tend to attack individual privacy, and harass SARA - things that were previously very sacred. The results of the study prove that between press freedom and violations of journalistic code of ethics and violence against journalists have a significant relationship, while violations of journalistic codes of ethics with violence against journalists also have a significant relationship, but between press freedom and violence against journalists have a relative relationship during the conflict. Aceh does not have a causal relationship, but after the peace of GAM Aceh - RI there is a very significant relationship, in fact it was carried out by former fighting elements in Aceh GAM and the TNI / Polri. To avoid continuing victims, journalists in Indonesia, especially Aceh is expected to be able to apply the Proportional and Professional Concept (2P); Professional as a basic competency in journalistic and proportional operations is a provision to face various threats and dangers in fieldo perations.
\end{abstract}

\section{Keywords:}

press freedom; code of ethics; violence against journalists

\section{Introduction}

In addition to the function of 'ubudiyah, the waqf also functions as an effort to create and maintain hablun min Allah and hablun min an-nas. In its function as worship, waqf is expected to be a provision for the life of the wakif (person who has waqf) in the future. Waqf is a form of charity whose rewards will continue to flow as long as the waqf property is utilized. In a hadith it is explained that there are three things that will continue to flow the benefits of a person's deeds until after he dies, namely:

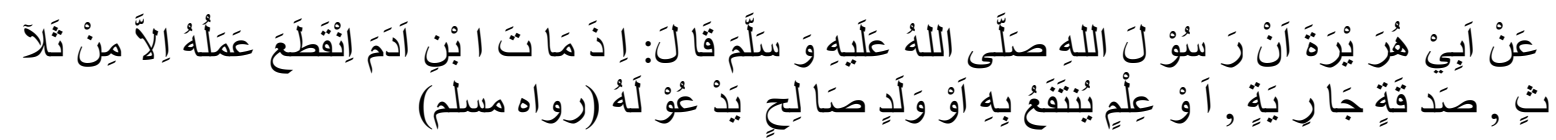

Meaning: From Abu Hurairah, the Messenger of Allah said: when Adam's son (human) dies his deeds will be cut off, except for three things: shadaqah Jariyah, useful knowledge and pious children who pray for their parents. (H.R, Muslim). 
Waqf is one of the potential sources of funding for Muslims that needs to be developed and managed professionally to obtain optimal benefits in the context of alleviating poverty and the welfare of Muslims themselves. To mobilize the potential of waqf, it is necessary to have a partnership from a waqf institution formed by the government, where the members consist of Nazhires in society and the government in a professional manner. Amal (2018) state that the phenomenon of the emergence of a government program of partial and sectarian government empowerment has been the concern of many circles.

In Law Number 41 Year 2004 in article 42 it is explained that "Nazhir is obliged to manage and develop waqf assets in accordance with their objectives, functions and allotments" and Article 42 paragraph (2) explains that "Management and development of waqf assets as referred to in paragraph (1) is carried out productively". Thus, Law Number 41 of 2004 concerning Waqf is projected as a means of social engineering, making changes in the thoughts, attitudes and behavior of Muslims to be in line with the spirit of the Waqf Law.

Waqf itself can be developed in accordance with the times with Islamic principles and goals. The purpose of Islamic teachings is to achieve the benefit of mankind, while the principles of sharia objectives consist of three main points, namely mashlahat dlururiyat, maslahat hajiyat and maslahat tahsiniyat. While waqf is included in the maslahat tahsiniyat, the importance of improving the quality of life.

The waqf provisions meant here are of course binding rules of waqf (consisting of pillars, other terms and conditions) that must be fulfilled in the practice of waqf processions. So in this case the provisions as described from the formulation of the definition of waqf, include the pillars (principal elements of waqf) and other aspects of the provisions of waqf as detailed in the following explanation (Kamal, 2019).

The practice of waqf that occurs in the community has not been fully organized and efficient, so that in various cases the property of waqf is not properly maintained, neglected or transferred to the hands of third parties by violating the law. This situation is not only due to the negligence or inability of nadzir in managing and developing waqf assets but also because of the attitude of the public who do not care about or do not understand the status of waqf assets which should be protected for the general welfare in accordance with the purpose, function and allotment of waqf.

Waqf institution is one of the economic pillars in Islam which is closely related to the socio-economic problems of society. Quite a number of countries with developed waqf management are able to solve their socio-economic problems with waqf. Unfortunately, the understanding of Islamic ummah in Indonesia regarding waqf for centuries has been very limited to waqf for immovable objects, especially waqf in the form of land.

In terms of waqf management, it is important to get attention, because waqf is a form of worship in Islam which has productive economic value. In addition, waqf consists of movable objects, including cash, shares, savings, investment, production, leasing, long and useful waqf and immovable objects, such as mosques or musholla, madrasah, agricultural land / gardens, among others. Strategic land, grave land, malls, offices, Islamic Center, and patents. The management and development system can be done through, among others; planning, organizing, implementing in a trustworthy and professional manner as well as responsible supervision; empowerment and investment partnerships, cooperation with banking institutions, financial institutions, both domestic and foreign. 


\section{Research Methods}

This research is a social research. It is said so because research is conducted to see social symptoms or social facts that occur in society. The research method used in this discussion is a qualitative research method, namely an approach that the discovery procedure is carried out not using statistical or quantification procedures. The approach that the writer uses in this discussion is an empirical or sociological approach, which is an approach that focuses on the practice and behavior of Muslims in relation to syariah.

\section{Discussion}

\subsection{Theory of Productive Waqf}

Productive in the sense of language, namely producing a lot; Productive in nature, according to the term productive waqf, namely property waqf which is used for production purposes in the fields of agriculture, trade, industry and services, the benefits of which are not directly on objects, but from the net profits resulting from the development of waqf which are given to people who are entitled accordingly with the aim of waqf. Here, productive waqf is processed to produce goods or services which are then sold and the results used in accordance with the purpose of waqf.

According to Mundzir Qahaf, productive waqf is property or fixed principal that is donated to be used in production activities and the results are distributed according to the purpose of the waqf. It is hoped that the benefits of productive waqf can support and finance the social service functions of waqf. Productive waqf, for example, are in the form of rice fields, gardens, fish ponds, shops, apartments and hotels. The explanation above means that the waqf object which is used in production activities is utilized by the recipient of the waqf according to the agreement between the waqf giver and the recipient of the waqf. Besides that, waqf objects cannot be owned individually or individually, but waqf objects are the property of Allah SWT.

Law Number 41 of 2004 concerning waqf has urgency, that is, apart from the interests of mahdhah worship, it also emphasizes the need for productive empowerment of waqf for social interests (the welfare of the people). Management of a waqf cannot be separated from the role of a Nazhir. This is due to the development of waqf assets depending on a Nazhir. Although the mujtahids did not make Nazhir one of the pillars of waqf, the scholars agreed that they had to appoint Nazhir, in Indonesia Nazhir was established as the main basis for waqf.

Basically, waqf is productive in the broad sense of producing because waqf can fulfill its purpose if it has produced where the results are used according to its purpose (mauquf alaih) According to the opinion of some scholars, it was Umar bin Khatab who first implemented the waqf Sharia. This opinion is based on the hadith narrated by Ibn Umar, ra, he said:

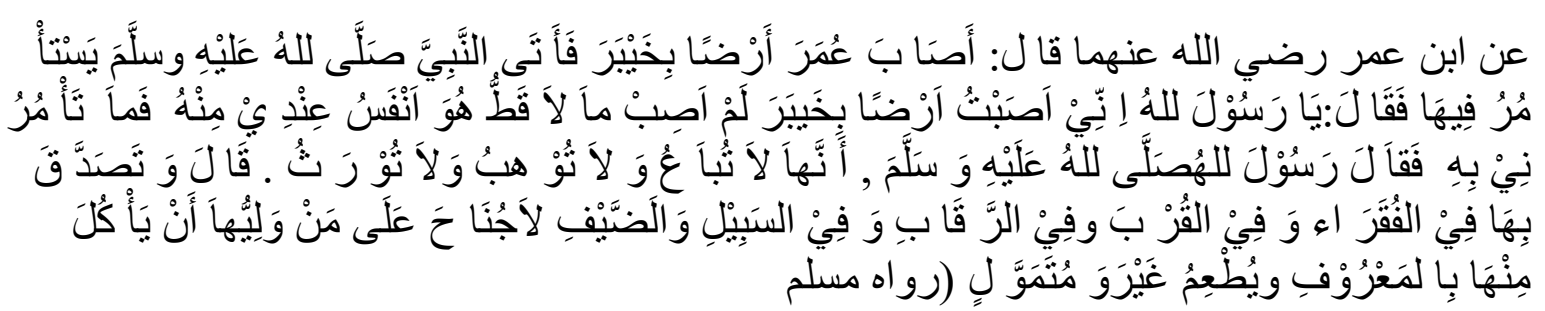


Meaning: From Ibn Umar r.a said: "That friend of Umar ra. Obtained a plot of land in Khaibar, then Umar ra. facing Rasulullah saw. to ask for directions. Umar said: O Rasulullah SAW., I got a piece of land in Khaibar, I haven't got that kind of wealth, so what do you order me? Rasulullah SAW said: "If you like, you hold (in essence) the land, and you give (the result). "Then Umar donated (the land to be managed), not sold, not granted and not inherited. Ibn Umar said: "Umar donated it (the results of land management) to needy people, relatives, servants, sabilillah, ibnusabil and guests and it is not forbidden for those who manage (Nazhir) waqf to eat from the results in a good way (properly) or feed others with no intention of accumulating wealth ". (HR. Muslim).

Then the waqf shari'a that was carried out by Umar bin Khathab was followed by Abu Talha who donated his favorite garden, the garden of "Bairaha". Furthermore, by other companions of the Prophet SAW, such as Abu Bakr who donated a piece of his land in Mecca for his descendants who came to Mecca, Uthman Bin Affan donated his wealth in Khaibar, Ali Bin Abi Talib who donated his fertile land.

From the hadith above we can see that the waqf made by Umar bin Khaththab and the other companions of the Prophet is included in the context of productive waqf in the sense of bringing economic aspects and community welfare where waqf is intended for productive business and the results obtained from waqf Produtif can be the economic empowerment of the people. Ironically, in Indonesia there is a lot of public understanding that assumes that waqf is unproductive and even dead land that requires costs from the community, such as for cemeteries, mosques etc.

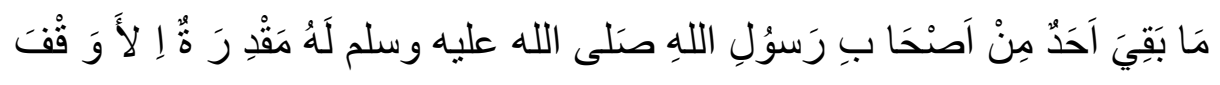

Meaning: None of the Prophet's companions had the ability except for waqf.

So the main characteristic of productive waqf lies in the management pattern and ways of preserving waqf, part of the productive waqf is used to care for and preserve waqf objects and the rest to be given to people who are entitled according to the purpose of waqf. Productive waqf can be seen from the purpose of the waqf management itself, the management that provides guidance and services to a number of assets aimed at realizing the maximum possible benefits. Management objectives can be summarized as follows:

1. Increase the feasibility of producing waqf assets to achieve the ideal target to provide the greatest possible benefit for the purpose of waqf.

2. Protecting the principles of waqf assets by maintaining and maintaining good in investing in waqf assets and reducing the risk of investment as small as possible, because waqf assets are a source of enduring funds whose results are distributed for various good purposes.

3. Perform the task of distributing the results of waqf properly to the predetermined ends of the waqf, based on the statement of the waqf in the waqf deed. As well as being required to keep up with ongoing social and economic changes, and to have the administrative capacity to make appropriate decisions, in order to cope with any changing situations and conditions.

4. Adhere to the wakif requirements, whether it is with regard to the type of investment and its objectives or with the purpose of waqf, the recognition of its object and the boundaries of its place, or the form of management and the ins and outs of how Nazhir can occupy that position.

5. Provide explanations to benefactors and encourage them to undertake new waqf, and in general provide counseling and suggest the formation of new waqf both verbally and by way of example. 
From the definition of productive waqf above, it is very clear that waqf which has religious and economic values is needed as a support for social life to create common welfare, especially in today's life.

\subsection{Increasing Economic Empowerment of People through Productive Waqf a. Productive Waqf Management}

In an effort to manage waqf productively, the party that plays the most successful role or not in the productive use of waqf assets is Nazhir waqf, which is a person or group of people or legal entities entrusted with the task of Wakif (the person who donates assets) to manage waqf. Meanwhile, according to law number 41 of 2004 article 1 paragraph (4) on waqf explains that Nadzir is the party who receives waqf property from wakif to be managed and developed according to its allotment.

Although in the Ulama fiqh books do not include Nazhir waqf as one of the pillars of waqf, because waqf is a tabarru '(sunnah gift) worship. However, after paying attention to the purpose of waqf, which is to preserve the benefits of the proceeds of waqf property, Nazhir's existence is very much needed and even occupies a central role. Because on Nazhir's shoulders, the responsibility and obligation to maintain, maintain and maintain and develop waqf and distribute the results or benefits of waqf to the target of waqf.

In addition, in an effort to manage waqf land productively, the role of Nazhir waqf as explained in Law Number 41 of 2004 in article 11 explains that the role of Nazhir waqf is:

a. Administering waqf assets;

b. Manage and develop waqf property in accordance with its purpose, function and allotment;

c. Supervising and protecting waqf property;

d. Report the implementation of tasks to the Indonesian Waqf Board.

There are 4 main factors in productive empowerment of waqf, namely: the economic potential of waqf, quality human resources, modern management and application of control and supervision systems. The steps that Nazhir must take according to the order of priority can be described as follows:

a. Mapping of the economic potential of the donated land.

Before the empowerment of the donated land is carried out, a mapping of the potential of the donated land must be made first, to what extent and to what extent can the waqf land be utilized and developed productively.

b. Quality human resources

Recruitment and readiness of Human Resources (HR) in productive business is an absolute matter. Professional and trustworthy human resources must be Nazhir's main concern who will empower the donated land. If Nazhir does not have good skills in development efforts, then Nazhir can entrust human resources who have good quality and high morality from various disciplines and skills.

c. Modern and professional management

In developing and managing waqf land productively, a modern, transparent, professional and accountable managerial pattern is required.

d. d. Application of control and supervision systems

In order for the empowerment and development of productive waqf to work properly, control and supervision can be applied in the internal management environment as well as from external circles such as the community, NGOs, academics, public accountants and so on. It is hoped that the implementation of control and supervision will prevent misuse and misuse of the donated land. 
Waqf which is managed with a system and management that is trustworthy, professional and integrated with guidance and supervision from the government and the community will stimulate the movement of the community's economy and make the social order healthy so as to further reduce the gap between wealthy groups of people and less fortunate groups of people.

\section{b. Development of Productive Waqf}

Breakthroughs regarding productive waqf have been regulated in various laws and regulations. This breakthrough is an awareness of the enormous potential / economic value of waqf, the breakthrough of productive waqf is intended to alleviate the problem of poverty as a phenomenon that constantly haunts a predominantly Muslim country like Indonesia, and poverty has become a culture in almost non-existent societies. The way out, government policies in order to overcome the social problems of society and the demands for welfare in this country do not lead to a solution. It would be too naive if the experts of Islamic law turn a blind eye without paying attention to the social problems of the community. Productive waqf is one of the policies in order to answer these social problems so that it becomes a necessity to promote productive zakat in order to improve the economy of the Islamic ummah in Indonesia.

In fact, people understand that waqf is still limited to traditional, which is still in the form of immovable physical objects, such as land, buildings intended for mosques, education, cemeteries, And Islamic Boarding Schools and so on. The use of waqf objects like this is still in the form of things that are physical in nature, so that it does not have an impact on economic improvement aimed at the welfare of the people. Based on data on waqf assets in the Ministry of Religion, where the number of waqf lands in Indonesia is 430,776 locations with an area of $1,615,791,832.27$ square meters which is the largest number of waqf assets in the world. The land which is worth trillions should be productive, besides that, Indonesia is the largest Muslim population in the world, with rich natural resources and waqf land which is part of Islamic teachings that have great potential for empowering Muslims, especially Muslims. it has not been cultivated optimally, even a lot of land is neglected and does not provide benefits for the welfare of the people. Therefore, it is a challenge and an opportunity for all groups to develop this land to be of economic value in helping the economic empowerment of the people and providing charity for the waqf who have donated their waqf land.

Waqf in its management requires funds to achieve the desired goals, so there must be a service provider project. It will not produce something like land waqf if it is not cultivated, for example by irrigation, the actual seeds have to spend money or it is called investment / investment. While the results after going through the investment and maintenance process. This expected income calculation is the economic feasibility study of a waqf asset project. With the development of figh for financial transactions in the last twenty years in line with the growth of Islamic financial institutions, it is easy to find new financing models for institutionally productive waqf projects.

Therefore, the current financing model must be based on well-known Islamic financing principles. In the traditional waqf property financing model, classic fiqh books discuss five models of waqf asset reconstruction financing, namely: Loans, Hukr (long-term lease contracts with large lump sum payments in advance), Al-Ijaratain (rent with two payments), adding assets new waqf and the exchange of substitutes (substitution) of waqf assets. Of these five models, only the addition of new waqf assets creates additional waqf capital and increases production certainty. While the other four models are mostly to finance operations and return the productivity of all waqf assets. 
The new financing model for institutionally productive waqf projects is as follows:

a. Murabahah Financing Model

The implementation of murabahah financing on project assets requires the manager of waqf assets (Nadzir) to take on the function of an entrepreneur (entrepreneur) who relies on an investment process that buys the equipment and materials needed through a Murabahah contract, while the financing comes from an Islamic bank.

b. Istisna 'Financing Model'

The Istisnaa model allows the manager of the waqf assets to order the development of the required waqf assets from a financing institution through an istisnaa contract. The finance institution or bank then makes a contract with the contractor to fulfill the order for the waqf asset manager on behalf of the financing institution. According to the Resolution of the Islamic Fiqh Academy of the OIC, Istisnaa is in accordance with a sharia contract where financing can be deferred on the basis of mutual agreement.

c. Ijarah Financing Model

This financing model is the application of Ijarah in which the manager of the waqf assets remains in full control of project management. In its implementation, the manager of the waqf assets provides a permit that is valid for only a few years to the fund provider to build a building on the waqf land. Then the manager of the waqf assets rents out the building for the same period of time that the financer owns it, and is used for the purpose of waqf. The waqf asset manager manages and pays the rent periodically to the fund provider.

d. Mudharabah by Asset Manager with Fund Providers

The Mudharabah model can be used by the manager of the waqf assets assuming a liquid role from or as an entrepreneur (mudharib) and by receiving funds from a financing institution to build a building on the waqf land, drilling an oil well if the waqf land produces oil. Management will remain in the hands of the owner of the waqf assets exclusively and the profit sharing rate is determined in such a way as to cover business costs for management as well as the use of the land.

e. Ownership-Sharing Financing Model

The share ownership financing model can be used if two parties individually and freely own the same two things others, for example, where one each owns half of a plot of agricultural land without having a formal partnership agreement.

f. Profit Sharing Model (Output)

The profit sharing model is a contract in which one party provides fixed assets such as land for the other and shares the gross output between the two based on an agreed ratio. This financing model is based on Muzara'ah where the land owner provides land (machines) to farmers. In profit sharing, land management funds cannot be provided by the same party. In the production-sharing financing model, waqf provides land and other fixed assets owned by waqf, while financing institutions provide operational and management costs. Financing institutions can also provide part or all of the machines as long as the land is provided by non-management parties in accordance with Muzara'ah requirements.

g. Long Term Lease Model

The model in which management as well as institutional financing is at the last hand is one that leases waqf assets for a long period of time. The provider of funds takes responsibility for construction and management and pays periodic rent to the manager of the waqf assets.

\section{c. Factors Inhibiting Productive Development of Waqf.}

There are several factors that hinder the productive development of waqf, including the following:

1. The strength of the old Islamic understanding in managing waqf, such as the assumption that waqf belongs to Allah Almighty alone which cannot be changed / contested. With this understanding, so far Nazhir has not developed waqf productively. In addition, the 
understanding that waqf has a broader social function is not yet complete and is not limited to Madha worship.

2. Lack of socialization regarding productive waqf and also Law Number 41 of 2004 carried out by related parties such as the Indonesian Waqf Board (BWI) to Nazhirs, Nazirs said that there had never been any socialization regarding productive waqf and also the existence of a Law - Law Number 41 Year 2004 which regulates Nazhir's obligations to develop waqf productively.

3. Nazhir who are not professional yet, so that waqf has not been managed productively. Nazhir's position plays a very important role in realizing the goal of waqf which is to preserve the benefits of waqf.

There are several things that must be done in an effort to overcome the problems faced in the management of productive waqf so that it is maximized in terms of its benefits, including:

1. The need to promote the socialization of waqf based on Law Number 41 of 2004 concerning waqf and the Compilation of Islamic Law (KHI); which is the Unification of various schools of thought in the country with the hope that there will be an enlightenment of a broader, more flexible 0 understanding of national waqf so that the essence of the purpose of waqf for the benefit of the people can be realized and utilized more efficiently and effectively

2. The existence of cooperation between related agencies regarding the process of donated land certification; This cooperation must be carried out considering the obstacles to the waqf land certification process are not only related to one agency. There must be an MOU between the Ministry of Religion and BPN, both at the center and implemented in the regions. Regarding funding, so far, funding assistance through the DIPA at the Ministry of Religion for certification is still insufficient, so it needs to be added to the nominal value, it can also be done through an approach to the Regional Government by the Ministry of Religion so that the Regional Government includes the cost of certification of waqf land in the RAPBD.

3. Coaching and training Nazhir endowments; For the management of waqf assets to increase their productivity, it requires the development of waqf experts such as waqf law experts and Nazhir waqf. Nazhir must meet the conditions that allow, so that waqf can be empowered and more widely used in terms of use. If Nazhir is not able to carry out his duties (obligations), then the government in this case BWI is obliged to replace him by still explaining the reasons. The Indonesian Waqf Board is given the task of developing waqf productively by fostering Nazhir waqf (waqf manager) nationally, so that waqf can function to improve the standard of living of the community. Article 47 paragraph 2 states that the Indonesian Waqf Board is independent, and the government acts as a facilitator. The main task of this agency is to empower waqf through its guidance function, both for moving objects and moving objects in Indonesia so that it can empower the economy of the people. BWI's duties are regulated in Article 49 paragraph 1 of Law Number 41 of 2004, namely:

a. To provide guidance to Nazhir in managing and developing waqf assets.

b. Managing and developing waqf assets on a national and international scale.

c. Give approval and / or permit for changes in the allocation and status of waqf assets.

d. Dismiss and replace Nazhir.

e. Provide approval for the exchange of waqf assets, and

f. Provide advice and considerations to the government in formulating policies in the field of waqf. 
Besides having constitutional duties, BWI must work on the following areas of duty:

a. Reformulating the new Wakaf fikh in Indonesia, so that waqf can be managed more practically, flexibly and modernly without losing its character as an eternal Islamic institution.

b. Making policies and strategies for productive waqf management, disseminating the permissibility of waqf for movable objects and cash certificates to the public. Compiling and proposing to the government regulations in the field of waqf to the government.

Apart from the existing constraints, waqf has great potential to become a productive asset, which in the end is not only able to support socio-religious services, but is also directed to support various social justice initiatives and goals. Basically, waqf is productive in the sense that it must produce because waqf can fulfill its purpose if it has produced, where the results are used in accordance with the mauquf alaih (means or purpose of waqf).

Umar bin Khattab has proven the success of managing the donated land in Khaibar, Umar donated a fertile garden in Khaybar, then the garden is managed and the results are used for the benefit of the community. This is an example of productive waqf in history that productive land brings economic aspects and welfare of the people.

The empowerment of waqf land which is of a productive nature is deemed necessary in taking advantage of the land, so that dead lands can be produced and educational institutions established for example, so that they can be felt by the community, especially the donated land in disadvantaged areas. The lack of educational facilities in underdeveloped areas has made donated land a solution in providing educational advice on this waqf land as well as providing free education for the middle to lower class. Utilization of the mosque's vast land by renting it out to traders where the profits from the land rent are used for the cost of building and maintaining the mosque.

Construction of buildings that can be rented out to entrepreneurs so that the results can contribute to the maintenance costs for waqf lands that are managed productively. As well as the construction of hotels and hospitals from waqf land which are investment in nature and provide job opportunities for people to help in overcoming unemployment and the results of the investment in waqf land can be allocated to people in need so that they can alleviate poverty. In addition, productive waqf is also useful in infrastructure development in helping development in Indonesia.

As the invested haj funds aim to help build infrastructure for the implementation of hajj, productive waqf also has a greater potential than the hajj fund, apart from all the potential for productive waqf, the need for funding in the development of these waqf lands, the role of the government in all its policies Regarding productive waqf, the government should participate in funding lands that are compatible with economic value so that they can help in realizing the welfare of the people, which is also the government's duty and responsibility.

During its development, productive waqf has increased to cash waqf. The presence of cash waqf is very strategic for the economic empowerment of the ummah, without determining the limits of waqf and the level of waqf in a fiqh perspective, a waqif, does not need to wait to be rich or have a lot of money to contribute to spending his assets for cash waqf, a waqif can donate his money at any time and regardless of the amount, different from the determined amount and amount of zakat, cash waqf is an act of sunnah which limits the amount and amount of which is freed for waqif to issue it. 
This concept should be a religious spirit that encourages people to do waqf according to their abilities so that the number of waqifs will continue to increase and the amount of waqf funds collected will increase. Thus, this cash waqf provides an opportunity for everyone to participate in the economic development of the people.

\section{Conclusion}

Law Number 41 of 2004 concerning waqf has urgency, that is, apart from the interests of mahdhah worship, it also emphasizes the need for productive empowerment of waqf for social interests (the welfare of the people). Management of a waqf cannot be separated from the role of a Nazhir. This is due to the development of waqf assets depending on a Nazhir. The main characteristic of productive waqf lies in the management pattern and ways of preserving waqf, part of the productive waqf is used to care for and preserve waqf objects and the rest to be given to people who are entitled according to the purpose of waqf Productive waqf can be seen from the purpose of the waqf management itself, the management that provides guidance and services to a number of assets aimed at realizing the maximum possible benefits.

In increasing the economic empowerment of the people through productive waqf, a new financing model for institutionally productive waqf projects can be done by: purchase the necessary equipment and materials through a murabahah contract letter, while the financing comes from an Islamic Bank. The Istisna model allows the manager of the waqf assets to order the development of the required waqf assets from the financing institution through an istisna contract. The financing institution or bank then makes a contract with the contractor to fulfill the order of the waqf asset manager on behalf of the financing institution.

\section{References}

Amal, B.K. (2018). The Exploring of Marxism Regarding The Poverty Sustainability in Kampung Nelayan Seberang, Belawan, Indonesia. Budapest International Research and Critics Institute-Journal (BIRCI-Journal). 79-92.

Achmad Djunaidi and Thobieb Al-Asyar.( 2007) Menuju Era Wakaf Produktif, cet. Ke-4. Jakarta: Mumtaz Publishing.

Ash-Shan'aniy, Muhammad ibn Ismail. Subulus Salam. juz 3 Mesir: t.pn. t.th.

Az-Zuhaili,Wahbah. (2007).Fiqih Islam wa adillatuhu, cet. ke IX. terj. Abdul Hayyie Al-Kattani dkk. Damaskus: Darul Fikr.

Depag RI. (2006). Pedoman Pengelolaan dan Pengembangan Wakaf, (Jakarta : Direktorat Jenderal Bimbingan Masyarakat Islam Direktorat Pemberdayaan Wakaf.

Depag RI.( 2008). Panduan Pemberdayaan Tanah Wakaf Produktif Strategis di Indonesia. Jakarta : Direktorat Pemberdayaan Wakaf Dirjen Bimas Islam.

Departemen Agama RI.(2006). Direktorat pemberdayaan Wakaf, Direktorat Jenderal Bimbingan Masyarakat Islam, Pedoman Pengelolaan \& Pengembangan Wakaf. Jakarta.

Departemen Agama RI. (2007). Pemberdayaan Tanah Wakaf Secara Produktif: (Upaya pengembangan Potensi Ekonomi Umat). Jakarta: Dirjen Bimas Islam Direktorat Pemberdayaan Wakaf.

Departemen Agama RI. (2009). Perkembangan Pengelolaan Wakaf di Indonesia. Jakarta: Depag RI.

Direktorat Pemberdayaan Wakaf. (2013) Direktorat Jendral Bimbingan Masyarakat Islam, Dinamika Perwakafan di Indonesia dan Berbagai Belahan Dunia. Jakarta: Kemenag RI. 
Kamal, M. et al. (2019). Method of Instinbāth Law of Money Waqf Abu Hanifah Immediate Perspective. Budapest International Research and Critics Institute-Journal (BIRCIJournal). P. 304-313.

Muhammad Asy- Syaukany, Imam Muhammad bin Ali bin. (1994). Nailul Authar. jilid VI Bairut: Darul Ma'rifah.

Pagar. (2010). Himpunan Peraturan Perundang-Undangan peradilan Agama di Indonesia,. Medan : Perdana Publishing.

Partatnto and Dahlan Al Barry. (1994). Kamus Ilmiah Populer. Yogyakarta: Arkol.

Qahaf, Mundzir. (2005). Manajeman wakaf produktif. PT Khalifa, Jakarta.

Salim and Sahrum. (2010). Metodologi Penelitian Kualitatif. Bandung :Cita Pustaka.

Undang-Undang Nomor 41 Tahun 2004 